University of Nebraska - Lincoln

DigitalCommons@University of Nebraska - Lincoln

USDA Wildlife Services - Staff Publications

U.S. Department of Agriculture: Animal and Plant Health Inspection Service

2011

\title{
Absence Of Mycobacterium Bovis In Feral Swine (Sus Scrofa) From The Southern Texas Border Region.
}

\author{
Tyler A. Campbell \\ USDA/APHIS/WS National Wildlife Research Center, tcampbell@eastfoundation.net \\ David B. Long \\ USDA WS National Wildlife Research Center, Fort Collins, CO \\ Luiz R. Bazan \\ USDA-APHIS-Wildlife Services \\ Bruce V. Thomsen \\ USDA-APHIS Veterinary Services Laboratories \\ SueLee Robbe-Austerman \\ USDA-APHIS Veterinary Services Laboratories
}

See next page for additional authors

Follow this and additional works at: https://digitalcommons.unl.edu/icwdm_usdanwrc

Part of the Environmental Sciences Commons, and the Life Sciences Commons

Campbell, Tyler A.; Long, David B.; Bazan, Luiz R.; Thomsen, Bruce V.; Robbe-Austerman, SueLee; Davey, Ronald B.; Soliz, Liza A.; Swafford, Seth; and Vercauteren, Kurt C., "Absence Of Mycobacterium Bovis In Feral Swine (Sus Scrofa) From The Southern Texas Border Region." (2011). USDA Wildlife Services - Staff Publications. 1023.

https://digitalcommons.unl.edu/icwdm_usdanwrc/1023

This Article is brought to you for free and open access by the U.S. Department of Agriculture: Animal and Plant Health Inspection Service at DigitalCommons@University of Nebraska - Lincoln. It has been accepted for inclusion in USDA Wildlife Services - Staff Publications by an authorized administrator of DigitalCommons@University of Nebraska - Lincoln. 


\section{Authors}

Tyler A. Campbell, David B. Long, Luiz R. Bazan, Bruce V. Thomsen, SueLee Robbe-Austerman, Ronald B. Davey, Liza A. Soliz, Seth Swafford, and Kurt C. Vercauteren 


\title{
Absence of Mycobacterium bovis in Feral Swine (Sus scrofa) from the Southern Texas Border Region
}

\begin{abstract}
Tyler A. Campbell,, ${ }^{1,7}$ David B. Long, ${ }^{1}$ Luis R. Bazan, ${ }^{2}$ Bruce V. Thomsen, ${ }^{3}$ Suelee Robbe-Austerman, ${ }^{3}$ Ronald B. Davey, ${ }^{4}$ Liza A. Soliz, ${ }^{1}$ Seth R. Swafford, ${ }^{5}$ and Kurt C. VerCauteren ${ }^{6}{ }^{1}$ United States Department of Agriculture, Animal and Plant Health Inspection Service, Wildlife Services, National Wildlife Research Center, MSC 218, 700 University Blvd., Kingsville, Texas 78363, USA; ${ }^{2}$ United States Department of Agriculture, Animal and Plant Health Inspection Service, Wildlife Services, San Diego, Texas 78384, USA; ${ }^{3}$ United States Department of Agriculture, Animal and Plant Health Inspection Service, Veterinary Services, National Veterinary Services Laboratories, 1920 Dayton Ave., Ames, lowa 50010, USA; ${ }^{4}$ United States Department of Agriculture, Agricultural Research Service, Cattle Fever Tick Research Laboratory, 22675 N. Moorefield Rd., MAB 6419, Edinburg, Texas 78541, USA; ${ }^{5}$ United States Department of Agriculture, Wildlife Services, 1714 Commerce Court, Suite C, Columbia, Missouri 65202-1594, USA; ${ }^{6}$ United States Department of Agriculture, Wildlife Services, National Wildlife Research Center, 4101 La Porte Ave., Fort Collins, Colorado 80521, USA; 7 Corresponding author (email: tyler.a.campbell@aphis.usda.gov)
\end{abstract}

ABSTRACT: Free-ranging wildlife, such as feral swine (Sus scrofa), harbor a variety of diseases that are transmissible to livestock and could negatively impact agricultural production. Information is needed regarding the exposure and infection rates of Mycobacterium bovis and many other diseases and parasites in feral swine occurring in the Texas border region. Our main objective was to determine exposure rates and possible infection rates of $M$. bovis in feral swine by opportunistically sampling animals from the Texas border region. From June to September 2010, we obtained samples from 396 feral swine and tested 98 samples for $M$. bovis by histopathology and mycobacteriologic culture. We found no evidence of $M$. bovis infection. We believe that it is important to periodically and strategically sample feral swine for $M$. bovis in high-risk areas of the United States because they are capable of becoming reservoirs of the disease.

Key words: Brucella, feral swine, Mycobacterium bovis, porcine parvovirus, pseudorabies virus, surveillance, Sus scrofa, Type A influenza virus.

Feral swine (Sus scrofa) are a reservoir of diseases of domestic livestock and are a potential disease threat to livestock production (Wobeser, 2006). Worldwide, exposure rates to several pathogens, such as Mycobacterium bovis (Vicente et al., 2006), Type A influenza virus (Hall et al., 2008), pseudorabies virus (PRV; Campbell et al., 2008), and Brucella suis (Campbell et al., 2008), can be high (30-80\%). Feral swine regularly come in contact with transitional domestic swine at sites with low biosecurity where they can introduce diseases into domestic herds (Wyckoff et al., 2009). Additionally, the occurrence of the cattle tick (Rhipicephalus annulatus) and southern cattle tick (R. microplus) in the southern Texas border region has been linked to white-tailed deer (Odocoileus virginianus; Pound et al., 2010); although it is not believed that feral swine are suitable hosts for these ticks.

There is little information on what diseases and parasites circulate with feral swine populations of the Texas border region. This information is needed to understand risks from trans-boundary diseases and to devise and evaluate control strategies. Information from the Texas border region is of particular importance because of the natural movements of wildlife, legal movements of livestock, and illegal movements of animals and animal products from and to Mexico, where many of the aforementioned pathogens, including $M$. bovis, are present in domestic livestock. Our objectives were to 1) determine exposure rates and possible infection rates of $M$. bovis in feral swine, 2) determine tick prevalence rates by genus on feral swine, and 3) serologically evaluate exposure to PRV, Brucella, porcine reproductive and respiratory syndrome virus (PRRS), porcine parvovirus (PPV), Type A influenza virus, and classical swine fever virus (CSFV) by opportunistically sampling feral swine from the Texas border region.

From June-September 2010, we sampled 396 feral swine collected as part of 
routine feral swine damage abatement activities in Brooks, Dimmit, Duval, Kenedy, Maverick, Webb, and Zapata counties in southern Texas (Fig. 1). The collection site in Zapata County was within the permanent quarantine zone of the United States Department of Agriculture, Animal and Plant Health Inspection Service (USDA APHIS) Veterinary Services Cattle Fever Tick Eradication Program, and Rhipicephalus spp. recently had been found on cattle. We trapped swine using $2.5 \times 1.2 \times 1 \mathrm{~m}$ portable box traps with fermented corn as bait. Captured feral swine were humanely euthanized (AVMA, 2007), and we determined age as adult or juvenile using tooth wear and eruption patterns (Matschke, 1967), sex, and weight. We collected a blood sample from each animal via cardiac puncture and lymph nodes (retropharyngeal, submandibular, parotid, mediastinal, tracheobronchial, and mesenteric) during necropsy from animals $>45 \mathrm{~kg}$. Lymph node samples were placed in $10 \%$ buffered formalin in jars for histopathology and frozen in whirlpaks at $-20 \mathrm{C}$ for culture. In Zapata County, we examined every feral swine for $5 \mathrm{~min}$ for ticks, including $2.5 \mathrm{~min}$ on the anterior (ears, head, and neck) and $2.5 \mathrm{~min}$ on the posterior (groin, tail, and haunches) areas of the animal. All ticks found were preserved in 91\% isopropyl alcohol for later identification. All procedures were approved by the Institutional Animal Care and Use committee at the National Wildlife Research Center (Permit QA-1749).

We performed histopathologic examination on formalin-fixed tissues that routinely were processed and embedded in paraffin, then stained with hematoxylin and eosin. Any granulomatous lesions suggestive of a mycobacterial infection were further evaluated with both modified Ziehl-Neelsen and auramine orange/acridine orange stains. We used mycobacteriologic culture detect acid-fast bacteria and further evaluated acid-fast positive samples for M. tuberculosis complex using

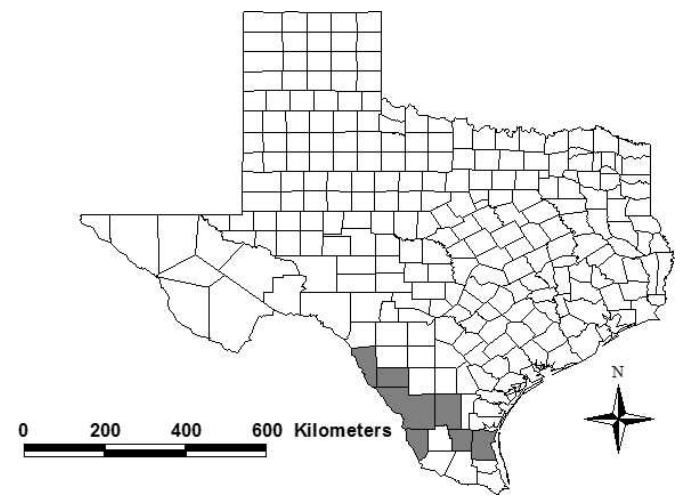

Figure 1. Distribution of counties (shaded) in the southern Texas border region from which feral swine samples were collected, June-September 2010.

a genetic probe (AccuProbe, San Diego, California, USA). Mycobacteriologic analyses were performed at the National Veterinary Services Laboratories (NVSL), Ames, Iowa, USA.

Serum was separated by centrifugation and samples were stored at $-20 \mathrm{C}$ until analysis. We used the Pseudorabies Virus Antibody Test Kit (Viral Antigens Incorporated, Memphis, Tennessee, USA), which used latex agglutination, to test for antibodies against PRV; the buffered Brucella antigen card test (NVSL) to determine antibodies against Brucella; the Idexx 2 XR enzyme-linked immunosorbent assay (HerdCheck PRRS 2XR Antibody Test Kit; Idexx Laboratories, Westbrook, Maine, USA) to test for antibodies against PRRS; a hemagglutination inhibition test for antibodies against PPV (Joo et al., 1976); an agar gel immunodiffusion assay for antibodies to Type A influenza virus (Hall et al., 2008); and an enzyme-linked immunosorbent assay and immunoperoxidase test for antibodies to CSFV. Serologic analyses for PRV, Brucella, PRRS, PPV, and CSFV were performed at the Texas Veterinary Medical Diagnostic Laboratory. Serologic analysis for influenza was performed at the USDA APHIS Wildlife Services, National Wildlife Research Center, Fort Collins, Colorado, USA. Ticks were identified to 
TABLE 1. Prevalence of ticks on feral swine collected in Zapata County, Texas by age, June-September 2010.

\begin{tabular}{ccccc}
\hline & \multirow{2}{*}{$\begin{array}{c}\text { Number of swine } \\
\text { examined }\end{array}$} & $\begin{array}{c}\text { No. of swine } \\
\text { with ticks }(\%)\end{array}$ & No. infested (\% infested) \\
\cline { 4 - 5 } Adult & 17 & $17(100)$ & $14(82)$ & $16(94)$ \\
Juvenile & 68 & $68(100)$ & $59(87)$ & $64(94)$ \\
Total & 85 & $85(100)$ & $73(86)$ & $80(94)$ \\
\hline
\end{tabular}

genus at the USDA Agricultural Research Service Cattle Fever Tick Research Laboratory near Edinburg, Texas. We report percent of feral swine exposed, infested, or infected by age.

We obtained feral swine tissue samples from 21 adults and 57 juveniles in Brooks County, 13 adults and 12 juveniles in Dimmit County, 25 adults and 78 juveniles in Duval County, 14 adults and seven juveniles in Kenedy County, 20 adults and 40 juveniles in Maverick County, six adults and 13 juveniles in Webb County, and 21 adults and 69 juveniles in Zapata County. Mean (range) weight of adults and juveniles were $57 \mathrm{~kg}(34-159)$ and $15 \mathrm{~kg}$ (134 ), respectively.

We performed histopathologic examinations on the head, thoracic, and abdominal lymph nodes from 98 adult animals. The majority (49/98) of feral swine had no significant lesions within the lymph node samples. Granulomatous lymphadenitis with no identifiable causative agent was identified in 18/98, and most of these lesions were small $(<1 \mathrm{~cm})$, highly mineralized, and surrounded by a thin rim of primarily macrophages and fibrous connective tissue. Eleven of 98 swine had granulomatous lesions which contained degenerate and nondegenerate spherules consistent with Coccidioides spp. Other lesions included eosinophilic lymphadenitis (8/98) and pyogranulomatous inflammation centered on Splendore Hoeppli material surrounding large colonies of coccoid bacteria (8/98). We performed mycobacteriologic culture on lymph nodes samples from the same 98 animals. Atypical mycobacteria were recovered from $65 / 98$ of the feral swine; however, no Mycobacterium tuberculosis complex organisms were identified. We found ticks on all feral swine sampled; however, we did not detect $R$. microplus or $R$. annulatus during our survey (Table 1). We found similar exposure rates between adult and juvenile swine for PRRS, PPV, and Type A influenza virus (Table 2). However, adult swine had PRV exposure rates eight times greater than juvenile swine. Exposure rates for PPV were high $(95 \%)$, and we did not detect antibodies to Brucella or CSFV (Table 2).

Given the occurrence of $M$. bovis within free-ranging Sus scrofa populations worldwide (e.g., Richomme et al., 2010), the absence of $M$. bovis in feral swine samples from this high-risk area was encouraging. We believe it is important to periodically and strategically sample feral swine for $M$. bovis in high-risk areas of the United States because they are capable of becoming reservoirs of the pathogen (Naranjo et al., 2008). Aiding such monitoring activities is the observation that feral swine readily display characteristic lesions (Martín-Hernando et al., 2007), and in many parts of the United States, feral swine are collected routinely as part of damage abatement activities. Collections of feral swine tissues in high-risk areas could be useful for detecting $M$. bovis within a variety of agroecosystems (Nugent et al., 2002). Similarly, the absence of Rhipicephalus spp. ticks on feral swine collected within quarantined pastures of the Cattle Fever Tick Eradication Program was a positive finding. This is true particularly because wild ungulates are recognized as reservoir hosts for cattle fever ticks (Pound et al., 2010). Our data indicate that 
TABLE 2. Summary of feral swine survey data for exposure to selected pathogens in seven counties in the southern Texas border region, June-September 2010.

\begin{tabular}{|c|c|c|c|c|c|c|}
\hline \multirow[b]{2}{*}{ Pathogen } & \multicolumn{3}{|c|}{ Adult } & \multicolumn{3}{|c|}{ Juvenile } \\
\hline & $n$ & No. positive & $\%$ positive & $n$ & No. positive & $\%$ positive \\
\hline Pseudorabies virus (PRV) & 105 & 61 & 58 & 174 & 12 & 7 \\
\hline Brucella & 103 & 0 & 0 & 174 & 0 & 0 \\
\hline $\begin{array}{l}\text { Porcine reproductive and } \\
\text { respiratory syndrome } \\
\text { virus (PRRS) }\end{array}$ & 37 & 1 & 3 & 97 & 1 & 1 \\
\hline Porcine parvovirus (PPV) & 38 & 36 & 95 & 99 & 94 & 95 \\
\hline $\begin{array}{l}\text { Type A influenza virus } \\
\text { Classical swine fever virus }\end{array}$ & 52 & 3 & 6 & 50 & 3 & 6 \\
\hline$(\mathrm{CSFV})$ & 67 & 0 & 0 & 76 & 0 & 0 \\
\hline
\end{tabular}

feral swine are not suitable hosts for the cattle tick and southern cattle tick.

Feral swine exposure rates to PRV were similar to others reported from the region. For example, in a recent study from southern Texas, overall feral swine PRV exposure rates were $35 \%$, with individual counties ranging from $7-100 \%$ (Campbell et al., 2008). In this study we found greater rates of exposure to PRV in adults than juveniles, providing indirect evidence supporting the hypothesis that PRV is primarily transmitted venereally among sexually active animals (Romero et al., 2001). Our feral swine exposure rates to PRRS and Type A influenza virus also were similar to others reported from this region (Campbell et al., 2008; Hall et al., 2008). Failure to detect antibodies to $\mathrm{CSFV}$ was expected given that this disease was eradicated form the United States in 1978. Nonetheless, we believe it is prudent to regularly sample feral swine from high-risk areas for agriculturally significant diseases that have been previously eradicated to provide further evidence that these diseases are not present. There was no serologic evidence of Brucella exposure in our samples, which was surprising because previous studies have identified antibody-positive feral swine from this region (Campbell et al., 2008).

Antibodies to PPV have been found in free-ranging Sus scrofa in the United
States (e.g., New et al., 1994) and throughout Europe (e.g., Lelešius et al., 2006). Our PPV exposure rates of $95 \%$ are the highest reported in the literature and could be due to active immunity or passive maternal immunity. These data suggest that PPV circulates actively in feral swine populations in the southern Texas border region, and the potential transmission to domestics exists (Wyckoff et al., 2009).

Wildlife disease monitoring and surveillance programs are critical for early detection of many diseases of agricultural importance (Salmon, 2003). Although these programs and activities can determine presence of a particular disease, not finding pathogens does not prove their absence. Strategic surveillance, targeting high-risk areas and wildlife species, is a prudent and cost-effective means of identifying disease incursions into the United States.

Our work was funded by the US Department of Agriculture. We thank C. Anderson, D. Bruning, J. Cumbee, J. Edwardson, T. Gidlewski, S. Goldstein, C. Hicks, A. Hildreth, A. Huerta, M. Lavelle, J. Lujans, M. Lutman, K. Pedersen, M. Pound, J. Rattan, T. Ruby, K. Shively, J. Stevenson, D. Walter, and A. Zamorano for field assistance. We are grateful to Texas Wildlife Services and the USDA APHIS WS National Wildlife Disease Program for providing logistic support and landowners for granting access. 


\section{LITERATURE CITED}

[AVMa] American Veterinary Medical Association. 2007. AVMA guidelines on euthansia. American Veterinary Medical Association, Schaumburg, Illinois, $27 \mathrm{pp}$.

Campbell, T. A., R. W. DeYoung, E. M. Wehland, L. I. Grassman, D. B. Long, and J. DelgadoACEvedo. 2008. Feral swine exposure to selected viral and bacterial pathogens in southern Texas. Journal of Swine Health and Production 16: 312-315.

Hall, J. S., R. B. Minnis, T. A. Campbell, S. Barras, R. W. DeYoung, K. Palilonia, M. L. Avery, H. Sullivan, L. Clark, and R. G. Mclean. 2008. Influenza exposure in feral swine from the United States. Journal of Wildlife Diseases 44: 362-368.

Joo, H. S., C. R. Donaldson-Wood, and R. H. Johnson. 1976. A standardized haemagglutination inhibition test for porcine parvovirus antibody. Australian Veterinary Journal 52 : 422-424.

Lelešius, R., V. Sereika, D. Zienius, and I. Michalskiené. 2006. Serosurvey of wild boar population for porcine parvovirus and other selected infectious diseases in Lithuania. Bulletin of the Veterinary Institute in Pulawy 50: 143147.

Martín-Hernando, M. P., U. Höfle, J. Vicente, F. Ruiz-Fons, D. Vidal, M. Barral, J. M. Garrido, J. de la Fuente, and C. Gortazar. 2007. Lesions associated with Mycobacterium tuberculosis complex infection in the European wild boar. Tuberculosis 87: 360-367.

Matschke, G. H 1967. Aging European wild hogs by dentition. Journal of Wildlife Management 31: 109-113.

Naranjo, V., C. Gortazar, J. Vicente, and J. de la FuEnte. 2008. Evidence of the role of European wild boar as a reservoir of Mycobacterium tuberculosis complex. Veterinary Microbiology 127: 1-9.

New, J. C., Jr., K. Delozier, C. E. Barton, P. J. Morris, And L. N. D. Potgieter. 1994. A serologic survey of selected viral and bacterial diseases of European wild hogs, Great Smoky Mountains National Park, USA. Journal of Wildlife Diseases 30: 103-106.
Nugent, G., J. Whitford, and N. Young. 2002. Use of released pigs as sentinels for Mycobacterium bovis. Journal of Wildlife Diseases 38: 665-677.

Pound, J. M., J. E. George, D. M. Kammlah, K. H. Lohmeyer, and R. B. Davey. 2010. Evidence for role of white-tailed deer (Artiodactyla: Cervidae) in epizootiology of cattle ticks and southern cattle ticks (Acari: Ixodidae) in reinfestations along the Texas/Mexico border in South Texas: A review and update. Journal of Economic Entomology 103: 211-218.

Richomme, C., M. L. Boschiroli, J. Hars, F. Casabianca, and C. Ducrot. 2010. Bovine tuberculosis in livestock and wild boar on the Mediterranean Island, Corsica. Journal of Wildlife Diseases 46: 627-631.

Romero, C. H., P. N. Meade, J. E. Shultz, H. Y. Chung, E. P. Gibbs, E. C. Hahn, and G. Lollis. 2001. Venereal transmission of pseudorabies viruses indigenous to feral swine. Journal of Wildlife Diseases 37: 289-296.

Salmon, M. D 2003. Animal disease surveillance and survey systems. Blackwell Publishing, Ames, Iowa, $222 \mathrm{pp}$.

[USDA APHIS] United States Department of Agriculture Animal and Plant Health Inspection SERvice. 2010. Guidelines for surveillance of bovine tuberculosis in wildlife. Wildlife Services National Wildlife Disease Program, Fort Collins, Colorado, $21 \mathrm{pp}$.

Vicente, J., U. Höfle, J. M. Garrido, I. G. Fernández-de-Mera, R. Juste, M. Barral, and C. Gortazar. 2006. Wild boar and red deer display high prevalence of tuberculosis-like lesions in Spain. Veterinary Research 37: 1-11.

Wobeser, G. A. 2006. Essentials of disease in wild animals. Blackwell Publishing, Ames, Iowa, 243 pp.

Wyckoff, A. C., S. E. Henke, T. A. Campbell, D. G. Hewitt, and K. C. VerCauteren. 2009. Feral swine contact with domestic swine: A serologic survey and assessment of potential for disease transmission. Journal of Wildlife Diseases 45 : 422-429.

Submitted for publication 7 February 2011. Accepted 2 May 2011. 